\title{
The Closing of the Sociological Mind?
}

ROSAIRE LANGLOIS

\begin{abstract}
D emographic explosions, ever higher literacy demands, and the revolution in communications have combined and conspired to create an avalanche of research in all fields. In just the past few years, received views of the decline of the Roman Empire, the Renaissance, the nature of Confucianism, and the influence of Zoroastrianism are only some of the re-evaluations underway. Why should the traditional view of the "rise of the West" - the "orthodox consensus" - be immune to this wider phenomenon of historical reconsiderations? This is perhaps the larger context in which Bryant's response to revisionism in modern world history should be seen. Bryant defends the conventional view that Europe's cultural and institutional structures "unfolded cumulatively over the longue durée" (Bryant 2006: 410) promoting a developmental dynamism not found in Asia where political and social structures hindered parallel achievements. A countervailing proposal has been launched, claiming that Eurasian societies were all advancing along a broadly comparable course and that the Western breakthrough was late and lucky, based on the New World windfall and coal deposits in England. While making Europe's breakthrough appear somewhat less heroic, it may well be more realistic. This view, variously known as the New World History, or the California School, or "revisionism" as Bryant and some others designate it, is promoted by a number of historians and anthropologists though there is much disagreement even amongst themselves.

The carefully crafted critique launched by Joseph M. Bryant is unlikely to put the "revisionist" genie back into the bottle. Even if one fervently concurs with Bryant's superb summation of European and Asian social structural differences and shares his suspicions of the new demographic theories about China, (Langlois 2006a) one can still doubt that these variations sufficed to generate the monumental transformation of Europe from a Eurasian backwater to an industrial pioneer in 400 years, and there is no consensus on this question. The data that he marshals forth may be more brittle than he supposes, while many historians (e.g., Hamilton 1976) would not share his view about Europe's "developmental dynamism" (2006: 411, n3) and "inner dynamic" (410).
\end{abstract}


Bryant's exposé and critique may pose little challenge to revisionists because his statistics on imperialism are dated or doubtful, seriously understating the impact of imperial gains on Europe's modernization, in light of new works. His attribution to Europe of a "restless rationalism," whether measured by inventiveness or based on Weber's rationalization theory, or both, is contested by sound research. Bryant's attack on what he calls "polycentric analytics" along with their alleged errors, may demonstrate more verbal alacrity than real sociological problems. Gunder Frank's and Goody's previous works bear no trace of focusing merely on short term, "ephemeral causation." Furthermore, Bryant's critique of Goody on the global origins of democracy presents a rather romanticized view of European democracy, at odds with a grimmer reality of unstable institutionalization and hostility to democracy, while he remains oblivious to non-European examples. Finally his analysis of the roots of European conquest abroad is somewhat Eurocentric and anachronistic, projecting Europe's 18th and 19th century power capacities back on to Columbus and Cortez, ignoring that in 1492 Europe did not have that edge over its Eurasian neighbors, and that this earlier conquest was based more on germs than guns. Arguably this conquest was the most economically vital and catalytic enabling factor in Europe's later dominance, as many historians attest.

\section{IMPERIAL BENEFITS}

In my view, Bryant believes that the overall thrust of European modernization was essentially internally generated - though he, of course, admits much technological borrowing from Asia - and that he may not take seriously enough the attempts by Frank and Pomeranz to show that imperialism was perhaps as fundamental. "Standard 'eurocentric' accounts of the industrial revolution do recognize ... the benefits derived from colonial expropriation," he writes (433). However, almost in the next breath, his analysis suggests that the colonial and imperial impact on Europe was comparatively small, (less than ten percent of European trade (434). Citing O'Brien's data from 1982, he was perhaps unaware that O'Brien upwardly revised his view in 1990 (Findlay 2002). Moreover, in 1999, some new statistics emerged: from 1870-1914 British overseas possessions contributed "almost $40 \%$ of British GNP" (Offer 1994:710). Offer goes still further claiming that the web of trade, migration and finance contributed to the restructuring of modern Britain (708). Furthermore, Blackburn claims profits derived from the triangular trade furnished "anything from $20.9 \%$ to $55 \%$ of Britain's gross fixed 
capital" (1998:542, 517-18) In another study, Daron Acemoglu et al. conclude that the usual characteristics stressed by sociologists, specifically "culture, religious Protestantism, war-making, Roman heritage, and features of the European state-system" (2004:549) are not the most important factors in explaining modernization. They found the key variable to be, overwhelmingly, the Atlantic states' access to the "profits made in the Atlantic trade, colonialism and slavery" and the indirect impact of the beneficiaries on furthering political change (Acemoglu et al. 2004:550). Alfred Crosby writes that "it is hard to see how the [industrial revolution] could have come about without the Colombian exchange" (1994:21). These new findings however, still underestimate the impact for many reasons, notably, the incalculable optimism generated by the discovery of the Americas, as H.M. Robertson pointed out decades ago. Nor should we forget that the new world acted as a "safety valve," an outlet for the poor and the disadvantaged in Europe to seek a new life while simultaneously acting as a curb on dissent.

The above research is consistent with the views of Walter Prescott Webb, a former president of the American Historical Association, who argued that European modernization was determined mainly by the New World windfall (Findlay 2002) Webb maintained that Europe was poor, cold and "half starved" (Webb 1972:134; Blackburn 1998:561). Constantinople was lost to the Turks in 1453, while Europe's resource limits were being approached (Findlay 2002; Bartlett 1993). Europe had motive to explore further west while China still had, as Braudel famously said, its own "internal Americas" and as Pomeranz adds, Qing China added over $6,000,000$ square kilometers to its borders but without any precious metals windfall (Pomeranz 2006). Webb contended that without the American frontier and the resulting " 400 year boom," providing free land, resources, and endless opportunities for the European dissidents, poor and landless peasants, adventurers and merchants, "modern Europe would hardly have been considered modern at all" (1972:123). Herlihy has recently taken a similar view. E.J. Hamilton has also claimed that Europe was running out of gold and that without American bullion European debt would only have worsened, leading to stagnation (1976:875876). New World bullion shipped to Europe increased in each of the next three centuries, multiplying the world's supply of bullion by fifteen times (Barrett 1990).

Indeed it is odd to see the skeptical reaction to Pomeranz and Andre Gunder Frank's claims about the impact of the Americas on Europe's "take-off," because this notion was so widely accepted by so many for so long that, on this point, the alleged revisionists are merely revivalists. E.J. Hamilton, John Maynard Keynes, Geoffrey Baraclough, Clarleton 
Coon, Shepherd Clough, Lenksi, and arguably Braudel and Adam Smith - whom Frank proudly and repeatedly cites at length - all took this view. These distinguished scholars are not included (or included without qualification) in Bryant's consensus list, but they were neither mavericks nor eccentrics, their work caused neither sensation nor disapprobation, and their conclusion that imperialism was central to modernization was considered neither particularly contentious nor tendentious. Bryant repeatedly upbraids revisionists for "decontextualization and homogenization" but minimizing the impact of imperial benefits is an equally distorting decontextualization (439-440). ${ }^{1}$

\section{Restless Rationalism and Sociology's Teflon Theorist}

Similar doubts are raised by Bryant's claim that the West can be characterized by a "restless rationalism" (405) - Weber and Mann have both used the phrase "rational restlessness" (Mann: 1988:7-15) - and that it has fostered a culture of "continuous invention" (413) since Greek and Roman times, distinguishing Europe from the Rest. Whether Bryant is referring either to general inventiveness or to Weber's theory of "rationalization," or both, is not clear. Either position presents problems, however. While historians have partially revised their views of Europe's lackluster inventiveness in ancient and medieval times, nonetheless, the European record was not overly impressive and it remains true that Europe only surpassed China by 1600 (Diamond 1997:409; Murray 2003:198; McNeill 1986:62). We should also bear in mind Freeman's The Closing of the Western Mind (2003), reminding us of how the Church remained a hindrance to free expression long after the Dark Ages. The prosecution and execution of Giodarno Bruno in 1600, a scientist, and the prolonged house arrest of Galileo hardly reflect a restlessly rationalist society, nor does the European witch craze of the 17th century. In 1565, the Catholic Tridentene Index banned almost three quarters of the books printed in Europe. Pre-modern Europe hardly merits the special designation of restless rationalism.

What may have significantly helped to instigate Europe's modern "restless rationalism" were two external factors: the Arab introduction of the works of Aristotle along with their own elaborate contributions in the 12th century. Later, Europeans even learned Hindu-Arab business mathematics brought to Europe by Fibonacci in Liber abbaci in 1202. Secondly, the impact of the New World influenced Europe's scientific revolution. This was the view of J.B. Bury, according to whom, Bodin

1 Pomeranz effectively pre-empts any such charge (2000: 207). 
and later Bacon, were so impressed by the technology that led to the New World discoveries and the ensuing practical benefits, that science's value was proven (Bury 1955:54-55). According to Pollard "it was not a new scientific cosmology that opened up new continents, it was adventurers, explorers and merchants.... Science owed more to Columbus than he owed to scientists" (1968:28) and the resulting synergy between profits and hedonistic curiosity led to a feverish 300 years of technological developments (Diamond 1997:258-259). Profits from the West India trade would later finance James Watts's research on the steam engine (Blackburn 1998:551). The discovery of the Americas provided a huge mental jolt to Europe: new medicines, plants, and foods, discovered by natives of the Americas were now incorporated into European science. New ethical debates arose over the rights of tribal cultures, while More's Utopia, Montaigne's Noble Savage, upset the universe of political discourse. The contributions of Spanish researchers may have been ignored by Anglocentric bias (Canizares-Esquerra 2004).

Perhaps by "restless rationalism" Bryant has in mind Max Weber's theory of Western rationalization, a process Weber saw as beginning under ancient Judaism when, uniquely among world religions, it banished magic. As Zeitlin puts it, "devout Hebrews initiated the practice of breaking magic's hold upon the world. In so doing they 'created the basis for our modern science and technology and for capitalism" (1984: xi-xii, citing Weber 1961:265). Passed on imperfectly to Christianity and later, more vitally, to puritanical Protestantism, it was this feature that allegedly shaped European modernization and domination. Duchesne (2005:467) has more explicitly made this Weberian riposte to "revisionists" "Only the West saw ... rationalization of all areas of culture" such as law, music, religion, military, organization, and administration. While many sociologists continue to promote this theory, or merely assume it to be valid, religious scholars and historians have long rejected it. Voluminous research has shown how Jewish and Christian societies in Europe were pervasively engulfed in magic (Wilson 2000; Schafer 1990; Charlesworth 1977). Thorndike's classic multi-volume history of magic (praised in the Catholic Historical Review as the greatest American contribution to medieval history) and Trachtenberg's 1939 volume on Jewish magic were all ignored by sociologists for decades, while they were promoting Weber as an alternative to Marx (Gouldner 1970:121, 188-9). More recently Robert Marsh has shown Weber to have made several serious misconceptualizations of Chinese traditional law, and that his notion of "formal rational law" has been rejected as a model for modern law as well (2001). Similar misunderstandings, it is charged, entered into Weber's study of music in Egypt, India, and China. Weber's 
Eurocentrism caused him to ignore the bureaucratic production of music in Egypt, India, and China (Turley 2001). In spite of this, Weber stands immutable as sociology's Teflon theorist.

\section{Global Origins of Democracy: A Hidden History}

However unintentionally, Bryant's brief discussion of democracy is deceptive and defective, exaggerating both the success of democracy in Europe and its absence in Asia and elsewhere. Bryant dismisses Goody's Indian examples as "transitional" (414), leaving "not even a single case" (415) outside of Europe. However, wasn't Athenian democracy, lasting barely a century somewhat "transitional"? And what about those "constitutionally based political freedoms" (415) of medieval parliaments to which Bryant makes such positive reference? They were often ignored for decades by wily kings or stacked with royal favorites, or had their powers revoked altogether as absolute monarchs rose throughout Europe (Acton 1967; Tin-Bor Hui 2001). And what about the rights of merchants and the "municipal liberties" (416) that Bryant also lauds? Did they protect the Jews from expulsion from England and later from Spain?

European history has been overwhelmingly undemocratic, and its history has been highly romanticized and propagandized, according to Arblaster (1984). Democracy was a pariah word in Europe for 2300 years after the Athenian attempt (Roberts 1997). Voltaire, Montesqieu, Mill, and de Tocqueville were aristocratic liberals with little respect for common people. Democracy was essentially a feature of the 19th and 20th centuries: even in 1863, John Stuart Mill, disdainful of mass suffrage, still advocated plural votes for elite males (Arblaster 1984). Universal suffrage was granted only to men in 1918 and to women in 1928 in Britain, a decade after the Russian revolution, and perhaps not coincidentally: David Lloyd George remarked, "One Russia is enough." No sooner was democracy introduced, than fascism spread amidst fears of possible Marxist expansion and its threat to property. Strangely enough, as many have recognized, Hitler could very well have triumphed had it not been for the disproportional efforts of Stalin's Red Army. Western democracy, in effect, is beholden to Stalin. Where is Bryant's much touted path dependency here? Even universal suffrage has not put an end to plutocracy though, and Mosca, Mills, and Domhoff remain more relevant than ever.

The emphasis Bryant implicitly places on institutional success as the indicator of democracy can conceal as much as it reveals. Looking at China, and noting the ubiquity of peasant revolts over two millennia, with support from secret societies like the "Yellow Turban" and "White 
Lotus," and religious groups like Taoists and Buddhists, may reveal a great deal about desires for freedom even if little institutionalist headway was gained. Serf riots did lead to the abolition of serfdom, however (Jenner 1998). China has never been bereft of the idea of freedom (Needham 1956; Freiberg, 1968; Chesneaux 1968), though some recent studies - echoing Hegel - neglect precisely these writings, supposing instead, that democratic ideas emerging in early 20th century China were merely a Western import (Jenner 1998).

However, even before Marx and Engels wrote the Manifesto, the future leader of the Taiping revolutionary movement was organizing his militias for a rebellion that eventually captured 40 percent of China from 1850-1863 leading to over twenty million dead, abolishing private property, re-distributing land, abolishing foot binding, concubinage, and allowing women into the army and civil-service exams. This, the most radical revolution in world history, up to that time, merits hardly a footnote in most of our histories. Was China really behind the West in its desire for freedom and democracy? The Taiping revolution was put down, with the help of British and American forces, who preferred a more manipulable Manchu dynasty to retain power. The underlying discontent remained, however, through the Boxer rebellion and the rise of Mao making almost a century of revolution in China from the 1840s to the 1940s. Aware of these events, and witnessing the beginning of communism, Weber wrote of Asian fatalism, while Marx, earlier on, wrote of the conservatism of the peasantry, both views now questionable.

The peculiarities of this movement, should not blind us to the obvious similarities to Anabaptist communism in Europe, and to other millennial revolutionary movements, so widespread among oppressed groups throughout world history (Langlois 1999), and a prelude to the coming communist revolution fifty years later. Of course, the resulting positive freedom can be dismissed as fraudulent or as "totalitarian freedom" in another Eurocentric attempt to claim exclusivity for its own version of democracy. It is difficult, especially in the wake of post-1989 euphoria, to say anything at all positive about communism, but is it not equally facile to deny any democratic content whatsoever to communist societies? Particularly useful in this regard, are Aronson's skeptical thoughts on the Black Book of Communism (Aronson 2003). Many earlier scholars, moreover, notably, C.B. Macpherson in his CBC Massey lectures accepted the communist claims of democracy to be broadly legitimate (1965). In addition, "the logic of industrialism" theorists, such as Clark Kerr, assumed that both industrial variants, capitalism and communism, would necessarily come to resemble each other more if only because of the common dictates of industrialism. Moshe Lewin (1988) demonstrated 
quite well that Gorbachev was likely a product of that very phenomenon. The post-1989 triumphalism in the West has led to a kind of selective amnesia towards many previous studies of communism that had a great deal of merit. Not completely however, for positive freedom is now a major discussion of Western political theorists including Rawls, Dworkin, Taylor, and others - a debate Durkheim would have welcomed who cannot reconcile the contradiction between the promise of equality of opportunity and the reality of unequal beginnings.

Finally, Europeans may not have been the first democrats: many hunting societies developed means of controlling alpha males, and Carthage in North Africa developed a democracy similar to Athens (Scheidel forthcoming). Amartya Sen (2003) has pointed out the Japanese equivalent of the Magna Carta as well as provided interesting details about Indian village republics, as does Muehlberger (1993). The Iroquois Confederacy is reputed to have influenced Thomas Jefferson in the framing of the American constitution, though it is much debated (Grinde and Johansen 1996).

Our abbreviated history of democracy should give some indication of why scholars such as Goody ${ }^{2}$ are concerned to look at the history of democracy in a new light and it seems harsh to consider such attempts as "directed less by a disinterested desire 'to get the history right' ... than by a politico-ethical need to suppress claims of difference through an agreeable invocation of imagined commonalities" (418).

\section{How the Great Divergence Happened: Projecting History BACKWARDS}

Emphatically denying that it was luck that led to European discoveries and conquest, Bryant appears to claim - in various parts of his essay - that it was Europe's "restless rationalism," and the accumulation of economic, political-administrative, technological, and scientific developments (435, note 29) as well as "technologically driven capitalism" (407) that made possible the growth of Europe's coercive power and industrialization. What is more, Bryant actually claims Europe possessed an "inner dynamic" (410). Europeans were "carriers of advanced sciences and technology" with "power capabilities of entirely new dimensions"

2 Goody (2006) elaborates on democracies. Amartya Sen (2003) develops a compatible approach. 
(435, note 29) allowing astonishingly small numbers (407) of Europeans to conquer overseas territories. ${ }^{3}$ Crudely put, European ingenuity.

While this portrait is surely correct for the late 18th and 19th centuries, it is not clear that Europe, in 1492, was more powerful in any of the above dimensions, including ingenuity, than its Eurasian neighbors. Militarily, China had handguns as early as 1288 (Pacey p. 47 Boot p. 21, Lynn 2004), and Asian merchants were highly skilled and aggressive, as decades of recent research have shown us. It should be kept in mind, what with Bryant's talk about advanced sciences, that Europeans still possessed typically Eurasian scientific and technological skills. At this time, guns, sails and compasses were indeed essential to European conquest of the New World (and essential to a classical Marxist interpretation of capitalist transition) but these instruments were arguably Asian inventions. European settlers furthermore, were not necessarily a highly skilled group; they were mostly landless farmers, and others who were desperate for new opportunities and a new life. Moreover, Bryant's "technologically driven capitalism," did not dominate Europe in 1492, though of course, over the next two centuries, the New World stimulus would vastly increase the size and power of the bourgeoisie allowing it to gain dominance over the aristocracy.

Even the importance of guns should not be over emphasized. What really enabled Europeans to conquer the Americas, as is well known, is simply that the Europeans carried germs (smallpox) for which New World peoples had not developed an immunity (Crosby 1985:200; Diamond 1997:210-11). Guns certainly did make a difference but natives could adapt even to them, and as late as the 1770s Benjamin Franklin seriously suggested that soldiers be equipped with bows and arrows since their flintlock rifles were cumbersome to reload, involving a 26 step process (Black 1991:61). Diamond adds, "Guns played only a minor role" (1997:76), in the conquest of the Incas. However, sparked by New World wealth, commercial wars and military escalation would ensue later.

The reader might, finally, simply ask: what if these Europeans, however skilled, had not found riches in the Americas but only desert and tundra? What would Europeans have then done? They would have been stuck in Europe in financial difficulty as Hamilton pointed out (1976). They would not have had the resources to buy goods from Asia, stimulate research, and provide an outlet for Europe's poor and disaffected.

Europeans weren't just lucky, they were lucky many times over: lucky the Americas were full of resources, lucky the inhabitants were

3 Besides Weber, Bryant is heavily influenced by Michael Mann, whose recent work has some commentators more perplexed than impressed (Langlois 2006b; Weitz 2005:1138-9). 
handicapped since the Ice Age without draft animals for agriculture and the urban societies it permitted. Europeans were lucky they unknowingly carried Old World germs to help fight the aborigines and lucky China was booming and had less incentive to search overseas (Findlay). Contra Bryant, Europeans were no more powerful than Asians in 1492 but 1492 would make them more powerful.

\section{Radical Contingency in History, Or Hysterics over Polycentric Analytics?}

Bryant is skeptical of the view that "geographical boons" can shape or reshape history. However, much of what is known with some certainty of world history has long been viewed as hinging on geography. Whatever you call it, "geographical determinism" or "influence" or "luck," these factors shape history to a large extent, setting limits on indigenous productive possibilities. Diamond's (1997) excellent contribution is only the most recent one. Perhaps it is sociologists who have underestimated the huge impact of geography on social structure (Stinchcombe 1983:20; Catton and Dunlap 1978).

The contingent discovery of the New World does give some measure of credibility to Bryant's claim that revisionists are radical contingency theorists but this is an exaggeration. After all, Goody, Frank, and Pomeranz would not deny that improvements in technology such as guns, sails, and the compass were the prerequisites of discovery. As Marxists would say, developments in the productive forces made possible the New World conquest. This, and the revisionists' emphasis on the economic windfall kick-starting developments in Europe, sharply distinguish them from genuinely radical contingency theorists like Ernesto Laclau, who reject any such materialistic approach.

Moreover, Bryant further overstates his case by making doubtful claims, i.e., revisionists "occlude" imperialism (440). That would be news to Gunder Frank who dedicated his academic life to explaining this very issue. Nor do revisionists endorse "ephemeral causality": For Goody, ecological differences between Africa and Eurasia had radical implications for both kinship and state structures (Langlois 2006a). ${ }^{4}$ Nor do revisionists "limit" (436) the scope of their research "only" to shortterm time periods, since both Frank and Goody reach back thousands of years in their search for the "origins of global hierarchies."

4 Goody's work has also been criticized as Eurocentric because of his insistence on the superior efficiency of the Western alphabet, while, in his view, European kinship gradually diverges from an older Eurasian pattern. Even Goody fits oddly into any Eurasian similarity thesis (Langlois 2006a). 


\section{Opening the Sociological Mind}

For a hundred years, sociological theorists have devoted scant attention to imperialism (Connell 2006; Magubane 2005). Columbus, as crucial in school history as he was to Adam Smith, somehow disappears in sociology. Revisionists have heroically resuscitated this crucial issue of imperial benefits. While sociologists have lavished attention on Weber - the very centerpiece of Bryant's "orthodox consensus" - they have neglected or snubbed such theorists as Mosca and Sorokin whose studies of elitism and cultural decline, still vital today, were perhaps far more disquieting to sociologists than Weber's reaffirmation of Western cultural and historical uniqueness. While Weber's continuing centrality is beyond question, mounting empirical evidence suggests that some central themes in Weber's gargantuan contribution are now looking increasingly suspect and shopworn, perhaps more grand mythopoetic fantasy of European superiority than grounded empirical theory. ${ }^{5}$

The provocative responses to revisionism by Bryant and Duchesne, both outstanding scholars, will enrich the debate immensely. The answers to these issues may not be coming soon, however, and generational change may gradually play a role in any paradigm shift or reform, as one sociologist saw it (Feuer 1974). Moreover, defenses of the orthodox consensus and exhortations to historians to read Weber (Duchesne 2006) will not hold back the tide of critical inquiry and appear more quixotic than convincing.

\section{REFERENCES}

Acemoglu, Daron, Simon Johnson, and James Robinson. 2005. The rise of Europe: Atlantic trade, institutional change and economic growth. American Economic Review 95(3):546-579.

Arblaster, Anthony. 1984. The Rise and Decline of Western Liberalism. Oxford: Basil Blackwell.

Aronson, Ronald. 2003. Communism's posthumous trial. History and Theory 42(2):222-245.

Barrett, Ward. 1990. World bullion flows 1450-1800. In James Tracy, ed., The Rise of Merchant Empires. Cambridge: Cambridge University Press.

5 Stark outspokenly points out how sociologists are "so well socialized into ancestor worship" (Stark 2004:465) and that it is time for this to end. Other signs of Weber's waning influence include Richard Hamilton's (1996) astute overview of the Protestant ethic debate as well as the recent paper by Colin Campbell, who notes how more sociologists are adopting positions at variance with Weber's (2006). 
Bartlett, Robert. 1993. The Making of Europe. Princeton: Princeton University Press.

Black, Jeremy. 1991. A Military Revolution? Atlantic Highlands, NJ: Humanities International Press.

Blackburn, Robin. 1998. Making of New World Slavery. London: Versao Press.

Boot, Max. 2006. War Made New. New York: Penguin Group.

Bryant, Joseph M. 2006. The West and the rest revisited: Debating capitalist origins, European colonialism and the advent of modernity. Canadian Journal of Sociology 31(4):403-444.

Bury, J.B. 1955 [1932]. The Idea of Progress. New York: Dover Publications.

Campbell, Colin. 2006. Do today's sociologists really appreciate Weber's essay The Protestant Ethic and the Spirit of Capitalism? Sociological Review 54(2):207-223.

Canivares-Esquera, Jorge. 2004. Iberian science in the Renaissance: Ignored how much longer? Perspectives on Science 12(1):86-124.

Catton, Willam R., Jr. and Riley, Dunlap. 1978. Environmental sociology: New paradigm. American Sociologist 13:41-49.

Chesneaux, Jean. 1968. Egalitarian and utopian traditions in the East. Diogenes 62:76-102.

Charlesworth, James H. 1977. Jewish astrology in the Talmud. Harvard Theological Review 70:183-200.

Connell, Raewyn. 2006. Northern theory: The political geography of general social theory. Theory and Society 35:237-264.

Crosby, Alfred. 1985. Ecological Imperialism. Cambridge: Cambridge University Press. 1994. Germs, Seeds and Animals. Armonk, NY: M.E. Sharpe. 1997. The Measure of Reality. Cambridge: Cambridge University Press.

Diamond, Jared. 1997. Guns, Germs and Steel. New York: W.W. Norton.

Duchesne, Ricardo. 2005. Defending the rise of Western culture against its multicultural critics. European Legacy 10(5):455-484.

2006. Max Weber is the measure of the West. World History Connected 4(1):1-10.

Feuer, Lewis. 1974. Einstein and the Generations of Science. New York: Basic Books.

Findlay, Ronald. 2002. Globalization and the European economy: Medieval origins to the industrial revolution. In Henryk Kierzkowski, ed., Europe and Globalization. London: Palgrave, Macmillan, Freeman, Charles.

Freeman, Charles. 2003. The Closing of the Western Mind. New York: Knopf. 
Freiberg, J.W. 1977. The dialectic of Confucianism and Taoism in ancient China. Dialectical Anthropology 2(3):175-198

Goody, Jack. 2006. Democracy, values and modes of representation. Diogenes 206:7-18.

Gouldner, Alvin W. 1970 The Coming Crisis of Western Sociology. New York: Basic Books.

Grinde, Donald and Bruce Johansen. 1996. Sauce for the goose: Regarding the Iroquois and democracy. William and Mary Quarterly 5393):621-636.

Hamilton, Earl J. 1976. What the New World gave the economy of the old. In Fredi Chiappelli, ed., First Images of America. Berkeley: University of California Press.

Hamilton, Richard. 1996. The Social Misconstruction of Reality. New Haven, CT: Yale University Press.

Herlihy, David. 1997. The Black Death and the Transformation of the West. Cambridge, MA: Harvard University Press.

Jenner, W. J.F. 1998. China and freedom. In David Kelly and Anthony Reid, eds., Asian Freedoms. Cambridge: Cambridge University Press.

Langlois, Rosaire. 1998. Internal proletariats and ancient religions: History reconsiders Rodney Stark. Method and Theory in the Study of Religion 11(3):299-324.

- 2006a. An introduction to Jack Goody's historical anthropology. In David Olson and Michael Cole, eds., Technology, Literacy and the Evolution of Society. London: Lawrence Erlbaum Associates Publishers.

— 2006b. Review of Dark Side of Democracy and Fascists. British Journal of Sociology 57(4):724-726.

Lewin, Moshe. 1988. The Gorbachev Phenomenon. Berkeley: University California Press.

McNeill, William H. 1986. Mythhistory and Other Essays. Chicago: University of Chicago Press.

Macpherson, C.B. 1965. The Real World of Democracy. Toronto: Canadian Broadcasting Corporation.

Magubane, Zine. 2004. Overlapping territories and intertwined histories. In Julia Adams, Elisabeth Clemens, and Skola Orloff, eds., Remaking Modernity. Durham, SC: Duke University Press.

Mann, Michael. 1988. European development. In Jean Baechler, John Hall, and Michael Mann, eds., Europe and the Rise of Capitalism. Oxford: Blackwell.

Marsh, Robert M. 1999. Weber's misunderstanding of traditional Chinese law. American Journal of Sociology 106(2):281-303

Muhlberger, Steven and Phil Paine. 1993. Democracy's place in world history. Journal of World History 4(1):23-46. 
Murray, Charles. 2003. Human Accomplishment. New York: Harper Collins.

Needham, Joseph. 1956. Science and Civilization in China. Vol. II. Cambridge: Cambridge University Press.

Offer, Avner. 1994. Costs and benefits, prosperity, and society 1870-1914. In Andrew Porter and Alaine Low, eds., The Nineteenth Century. Vol. 3. Oxford History of the British Empire. Oxford: Oxford University Press.

Pacey, Arnold. 1990. Technology in World History. Cambridge, MA: MIT Press.

Pollard, Sidney. 1971. The Idea of Progress. Harmondsworth, UK: Penguin Books.

Pomeranz, Kenneth. 2000. The Great Divergence. Princeton: Princeton University Press.

- 2006. Review of The Eastern Origins of Western Civilization. International History Review 28(2):350-352.

Roberts, Jennifer Tolbert. 1997. Athens on Trial. Princeton: Princeton University Press.

Schafer, Peter. 1990. Jewish magic literature in late antiquity and early middle ages. Journal of Jewish Studies 41(1):75-91.

Scheidel, Walter. Forthcoming. Layered states: institution, expansion and bargaining in ancient Mediterranean city-state empires.

Sen, Amartya. 2003. Democracy and its global roots. New Republic 6:28-35.

Stark, Rodney. 2004. SSSR Presidential address, 2004: Putting an end to ancestor worship. Journal for the Scientific Study of Religion 43(4):465-475.

Stinchcombe, Arthur. 1983. Economic Sociology. New York: Academic Press.

Tin-Bor Hui, Victoria. 2001. Emergence and demise of nascent constitutional rights: Comparing ancient China and early modern Europe. Journal of Political Philosophy 9(4):373-403.

Trachtenberg, Joshua. 2004 [1939]. Jewish Magic and Superstition. Philadelphia: University of Pennsylvania Press.

Turley, Alan C. 1995. Max Weber and the sociology of music. Sociological Forum 16(4):633-653.

Webb, Walter Prescott. 1972 [1951]. The frontier and the 400 year boom. In George R. Taylor, ed., The Turner Thesis. Lexington, MA: DC Heath and Co.

Weber, Max. 1961. General Economic History. New York: Collier.

Weitz, Eric. 2005. Review of Dark Side of Democracy. American Historical Review 110(4):1138-9.

Zeitlin, Irving. 1984. Ancient Judaism. Oxford: Basil Blackwell. 
Rosaire Langlois is Visiting Scholar in Religion at Trinity College, University of Toronto. He has contributed articles to The Social Philosophy of Ernest Gellner and to Technology Literacy and the Evolution of Society: Implications of the Work of Jack Goody. His recent review of Michael Mann's study of genocide appeared in the British Journal of Sociology in 2006 and he is continuing work on the issue of religion and genocide. rlanglois@trinity.utoronto.ca 